Summer 2005

\title{
Privatization, Prisons, Democracy, and Human Rights: The Need to Extend the Province of Administrative Law
}

Alfred C. Aman

Indiana University Maurer School of Law, aaman@indiana.edu

Follow this and additional works at: https://www.repository.law.indiana.edu/ijgls

Part of the Administrative Law Commons, Human Rights Law Commons, and the International Law Commons

\section{Recommended Citation}

Aman, Alfred C. (2005) "Privatization, Prisons, Democracy, and Human Rights: The Need to Extend the Province of Administrative Law," Indiana Journal of Global Legal Studies: Vol. 12 : Iss. 2 , Article 9. Available at: https://www.repository.law.indiana.edu/ijgls/vol12/iss2/9

This Symposium is brought to you for free and open access by the Law School Journals at Digital Repository @ Maurer Law. It has been accepted for inclusion in Indiana Journal of Global Legal Studies by an authorized editor of Digital Repository @ Maurer Law. For more information, please contact rvaughan@indiana.edu.

\section{$\Psi$}

JEROME HALL LAW LIBRARY

INDIANA UNIVERSITY

Maurer School of Law
Blooming ton 


\title{
Privatization, Prisons, Democracy, and Human Rights: The Need to Extend the Province of Administrative Law*
}

\author{
Alfred C. Aman, Jr.**
}

\section{INTRODUCTION}

Administrative law has an important role to play when it comes to providing democratic forums for deliberation and decisionmaking on a wide range of issues. In this paper, I will argue that domestic administrative law potentially offers a means for addressing human rights problems arising from privatization, particularly privatization in the United States dealing with prisons. As this paper will argue, creating opportunities for citizen involvement in what otherwise might be thought of as private decisionmaking processes may help prevent human rights problems before they occur. At a minimum, such an approach can create the forums and information necessary for meaningful and timely politics to develop around issues that, once privatized, can all too easily fall from public view. To make these arguments, this paper will focus exclusively on U.S. law as a case study of these issues.

Administrative and regulatory law scholarship in the United States traditionally has involved the study of two key relationships: the relationship of the individual to the state ${ }^{1}$ and the relationship of markets to the state. ${ }^{2}$ The first relationship-individuals and the state-involves analyses of the procedures used by administrative agencies as they seek to carry out their substantive statutory goals. As this paper will argue, analyses of the relative fairness, transparency, and public participation available to citizens in what many take for

*'This article was originally published in Privatisation and Human Rights in the Age of Globalisation (Koen De Feyter \& Felipe Gómez Isa eds., 2005). It is republished here with permission.

* Roscoe C. O'Byrne Professor of Law, and Director, Institute for Advanced Study, Indiana University-Bloomington. I wish to thank Professors Hannah Buxbaum, Carol Greenhouse, Christiana Ochoa, and Elizabeth Zoller for their most helpful comments and suggestions. I also wish to thank my research assistants, Aaron Furniss, class of 2004, and Helen Yu, class of 2006, for their excellent work.

1. See Harold J. Laski, The Foundations of Sovereignty (2003).

2. See Stephen Breyer, Regulation and Its Reform (1982). 
granted as wholly private domains is necessary. Administrative law now no longer can remain state centric in its focus.

The second relationship_-markets and the state-involves questions of the appropriateness of state intervention in markets to encourage or mandate certain outcomes or behavior. The substance and the perceived legitimacy of the law that develops from such interventions has had much to do with the procedures that ultimately implemented it. Particularly when legislation has involved ideological disagreements, continuing conflicts involving the legitimacy of the laws passed by Congress often have been expressed procedurally. ${ }^{3}$ Procedures and administrative structures have been substituted for alternative substantive political compromises. ${ }^{4}$ Today, markets are often substituted as a means for achieving public goals and resolving political disputes over how best to achieve them. The fusion of the market and the state in many contexts also requires a reassessment of the principles and reach of traditional administrative law.

Administrative law in the United States traditionally has been conceptualized in a state centric fashion-as a bridge between the market and the state. These two realms-markets and states-have stood for very different worlds, signaling binary approaches to obligations and constraints. ${ }^{5}$ Markets are said to stand for private ordering as opposed to state regulation; free markets as opposed to government bureaucracies. ${ }^{6}$ An important constitutionally based version of the public-private distinction derives from these differences. The state action doctrine is based on the explicit text of the Constitution imposing various restrictions on the exercise of state power: "Congress shall make no law,"7 "nor shall any State deprive any person of life, liberty, or property, without due process." ${ }^{.8}$ American administrative law has followed these broad constitutional outlines. It was created primarily for public bodies. ${ }^{9}$ Private actors and federal corporations have always played an important role in the regulatory process, but the resort to the market in

3. For a case study of the use of procedure and administrative structures as a substitute for substantive legislative compromises, see Alfred C. Aman, Jr., Institutionalizing the Energy Crisis: Some Structural and Procedural Lessons, 65 Cornell L. Rev. 493 (1980). See generally Paul R. Verkuil, The Emerging Concept of Administrative Procedure, 78 Colum. L. Rev. 258 (1978).

4. See Aman, supra note 3. See generally Verkuil, supra note 3.

5. See Saskia Sassen, The Mobility of Labor and Capital (1988).

6. See Milton Friedman, Capitalism and Freedom (1962).

7. U.S. Const. amend. I.

8. U.S. Const. amend. XIV, § 1.

9. See supra notes 7-8 and accompanying text. 
terms of regulatory approaches and structures has become increasingly common and is now very much a part of the regulatory landscape.

Privatization and various forms of private ordering, in general, have become more and more common as reforms, as we move from a focus on government to a study of new conceptualizations of the processes of governance. ${ }^{10}$ Privatization in the United States usually takes the form of giving over to the market the provision of services once provided by government. " For example, prisons, welfare, mental health facilities, and social services for the poor in general have all been subjected to the reform of privatization. ${ }^{12}$ The political decision to move a service or governmental responsibility from the public side of the ledger to the private side is consequential. It is, in effect, a decision to delegate governmental responsibilities to the market,$^{13}$ or a claim that the activities involved were not appropriate for governmental action in the first instance. ${ }^{14}$ Privatization subjects the activity in question to the forces of the market while freeing it from the various forms of regulation-both substantive and procedural - that apply to public bodies. This does not mean that no law applies; the common law and certain statutory laws may apply. ${ }^{15}$ Nevertheless, privatization of an industry or a social service usually means the Administrative Procedure Act (APA) ${ }^{16}$ does not apply, nor does the

10. See The Tools of Governance (Lester M. Salamon ed., 2002).

11. See Jody Freeman, The Private Role in Public Governance, 75 N.Y.U. L. Rev. 543, 552-53 (2000). For a discussion of some of the differences between privatization in Europe and the United States, see Giandomenico Majone, Paradoxes of Privatization and Deregulation, 4 Eur. Pub. Pol'y 53,55 (1994).

12. See Patricia M. Wald, Looking Forward to the New Millennium: Social Previews to Legal Change, 70 Temp. L. Rev. 1085, 1096-1100 (1997).

13. See Developments in the Law: The Law of Prisons, 115 HARv. L. REv. 1838, 1868-91 (2002).

14. See Richard J. Pierce, Reconsidering the Roles of Regulation and Competition in the Natural Gas Industry, 97 Harv. L. Rev. 345, 345 (1983); see, e.g., Edward W. Erickson et al., The Political Economy of Crude Oil Price Controls, 18 NAT. Resources J. 787, 800 (1978).

15. See, e.g., Richardson v. McKnight, 521 U.S. 399, 401-02 (1997).

16. The APA is a generic procedural statute passed in 1946 and intended to apply to many, if not most, of the federal agencies at that time. It set forth the basics as far as administrative procedure is concerned. It is premised on the idea that there are fundamental qualities that comprise what administrative adjudication or rulemaking should look like, no matter what the substantive issue may be or what agency may be involved. The APA has been supplanted by a variety of new substantive statutes in various specific areas, such as the environment, but I am using it primarily as a short hand way of referencing the fundamental values of administrative law-transparency, public participation, notice, a right to be heard, etc. Many of its procedural approaches remain $\mathrm{mmmm}$ 
Freedom of Information Act (FOIA)..$^{17}$ More important, market incentives and the profit motive may too easily be substituted for the public interest as well as for primary markers of programmatic success. ${ }^{18}$ There may be a partial convergence of market and public interest goals, as private actors strive to carry out their responsibilities in cost-effective and competitive ways. ${ }^{19}$ Without a ready flow of information about the substantive success of the regulatory missions involved, the bottom line takes on more and more significance as a measure of success. Such shifts in focus from public interest goals to the efficiencies of the market, coupled with economic assessments of what constitutes success, coincide with some uses of deregulation as well. ${ }^{20}$

Global competition, and the drive for lower taxes and lower regulatory costs that it encourages, accounts, in part, for the growth of what we might call a "nonstate public sector." This sector is one that evades the administrative law protections normally applied to a state entity, while bringing to bear the efficiencies of the market to the task at hand. Such approaches implicitly assume a zerosum public-private game-that is, as some matters are moved from the public to the private sphere, nothing fundamental changes in what we think of as public or as private. Markets are markets and the government is the government. If anything, government can only be improved by the demands of the market, but the two spheres remain relatively autonomous. Changes in technology or regulatory technique may favor one mode of regulation over another. Such change may be innovative, but it need not be seen as transformative in nature if all that changes is the relative degree of how much we now choose to make public and how much we now leave to the private sphere.

highly relevant today, but many were also devised with essentially a New Deal conception of regulation involved. See Administrative Procedures Act of 1946, 5 U.S.C. $\$ \S 551-559$ (2005). I do not argue that all of the APA's details remain relevant today, but rather that its core values and goals do and should persist.

17. Like the APA, FOIA applies only to "state agencies."

18. For a discussion of some of the conflict of interest concerns presented by a merger of profitoriented approaches with public interest goals, see Alfred C. Aman, Jr., Privatization and the Democracy Problem in Globalization: Making Markets More Accountable Through Administrative Law, 28 Fоrрнам URB. L.J. 1477, 1481-83 (2001) (discussing legitimate and illegitimate forms of global currency).

19. See Vice President Al Gore \& National Performance Review, From Red Tape to Results: Creating a Government That Works Better and Costs Less (1993).

20. For example, there have been various deregulatory and market-based approaches to environmental regulation. See generally Richard B. Stewart, Reconstitutive Law, 46 MD. L. Rev. 86 (1986). 
But this is not the case. It is not just the recourse to the market that makes such change significant, but the change itself, located in the underlying relationship of states to markets. It is the fundamental realignment in the way states and markets interrelate and, at times, even merge-blurring and erasing the boundary between the two that requires us to examine these delegations to the market at the domestic level as part of a larger picture. ${ }^{21}$ Several other forms of delegation of state power are involved, including: (1) various "de facto delegations" to the market that result from inadequate funding of the regulatory regime in place, ${ }^{22}$ (2) delegations to private transnational entities, ${ }^{23}$ whose regulation would most likely require a multilateral approach, as well as (3) delegations to international organizations such as the WTO; ${ }^{24}$ and (4) the devolution of federal responsibilities to states or, in effect, delegations to subnational or regional entities. ${ }^{25}$ The cumulative effect of all of these various delegations, especially privatization, amounts to a new situation that requires that we see administrative law in a new light. The newly enlarging private sphere is not the result of simply a shift of preference for the private over the public, or the international over the national, but a new way of organizing public responsibilities and politics. Indeed, the cumulative impact of these delegations (including the privatization of social services, the deregulation of various industries, and the increased reliance on such public policy tools as school vouchers, tax credits, and faith-based initiatives), in effect, privatizes the public square, disaggregating the public and fusing concepts of citizenship with consumerism. ${ }^{26}$

21. That larger picture is set forth, in detail, in Alfred C. Aman, Jr, The Democracy Deficit: Taming Globalization Through Law Reform (2004).

22. Some agency budgets have declined or have not kept pace with increased demands. See, e.g., Richard A. Oppel, Official Says SEC Strained, With Duties Exceeding Budget, N.Y Times, Mar. 6, 2002, at C13 (The GAO warned that the SEC does not have financing to manage its growing work load.). Enforcement activities in most agencies suffer from an inadequate staff. This puts additional pressure on and creates incentives for administrators to promulgate rules that set goals and standards whose enforcement is less labor intensive than command-control rules.

23. As Gunther Teubner argues, global law is made outside the political structures by private transnational actors. See Global Law Without a State (Gunther Teubner ed., 1996).

24. See Chantal Thomas, Constitutional Change and International Government, 52 Hastings L.J. 1 (2000).

25. See recent federalism cases discussed from a global perspective in Alfred C. Aman, Jr., Federalism Through a Global Lens: A Call for Preferential Judicial Review, Ind. J. Global Legal Stud., Winter 2004, at 109 (2004).

26. See Matthew A. Crenson \& Benjamin Ginsberg, Downsizing Democracy: How America Sidelined Its Citizens and Privatized Its Public (2002). 
Such changes do not argue for a return to the past. Rather, they constitute new regulatory and procedural questions that require new solutions. Some of the new questions are: how best can nonstate actors be involved in decisionmaking processes, ${ }^{27}$ how can we maximize the flow of information involving these decisions; ${ }^{28}$ and how can we mitigate conflict of interest concerns that arise from the fusion of public and private that typify many markets and market approaches to policy issues-issues ranging from private prisons to welfare eligibility. ${ }^{29}$ Fundamental issues of democracy are now at stake. ${ }^{30}$

My argument is in four parts. In Part I, I discuss the democracy deficit. In Part II, I discuss two approaches to globalization-state centric and denationalized, or pluralistic. As I have indicated earlier, ${ }^{31}$ various delegations of state power are important to the context I want to consider. In this paper, however, I will consider only one of these. Part III will discuss intrastate delegations from the public sector to the private sector, specifically, the privatization of prisons. I conclude that what appears to be an ever-growing private sector-created by delegations of public functions to private bodies (and international organizations as well) - is a crucial area for administrative law reform and an important way of guarding against human rights violations.

For my discussion of the democracy deficit, I will take as a baseline four general criteria: the participation of affected stakeholders, notice of the actions involved, transparency as to the outcomes and the reasons for those outcomes, and accountability for these decisions. The types of delegations mentioned above raise related democracy questions, but they embody different aspects of the democracy deficit in terms of these criteria. Shifts from the public sector to the market displace key stakeholders from participation. Shifts from the state to the international arena preserve a role for the domestic public sector, but, often, in a largely "rubber stamp" capacity.

27. In the context of the WTO, for example, see Daniel C. Esty, The World Trade Organization's Legitimacy Crisis, 1 World Trade Rev. 7 (2002).

28. See id.

29. Regarding welfare, see Matthew Diller, The Revolution in Welfare Administration, 75 N.Y.U. L. Rev. 1121 (2000); on prisons, see Developments in the Law: The Law of Prisons, supra note 13.

30. For a discussion of the democracy issues involved in various global contexts, see Symposium, Globalization and Governance: Prospects For Democracy, Ind. J. Global Legal Stud., Winter
2003, at 1-448.

31. See supra text accompanying notes 22-25. Portions of the text in Parts I, II, and III draw upon my work in The Democracy Deficit: Taming Globalization Through Law Reform,
supra note $2 \mathrm{l}$. 
These delegations also represent different aspects of globalization. How we understand globalization will greatly affect our sense of the law reforms that may be in order. Global processes intersect with state power in a variety of ways that can be arrayed along a continuum from state centric to what I call denationalization. ${ }^{32}$ These dimensions of globalization involve different sorts of democracy deficits and various potential roles for U.S. administrative law.

\section{The Democracy Problem}

The democracy problem in globalization arises from the disjunction between global economic processes (on the one hand) and local processes of democratic participation (on the other). By disjunction I refer to the exclusion of key stakeholders (or stakeholder communities) from the institutional processes whose outcomes affect them directly. When the resolution of such disjunctures is left to domestic or transnational markets, or international organizations that privilege market outcomes, such privatizations or market-oriented international regimes only intensify the democracy problem. ${ }^{33}$ By approaching these processes as if they were only unidimensional and subject either to the rules of the market or the more traditional and hierarchical approaches of public law, we simply reify the separate worlds of markets and states, without taking into account the ways globalization is changing these worlds and their relationship to each other, and without providing room for a debate and discourse to develop that include a meaningful politics involving noneconomic values. When regulation is given over to the market or international decisionmakers, the public is no longer involved directly in decisionmaking, nor is information usually available in a form that would make public participation meaningful. ${ }^{34}$ Market outcomes coupled with decisions not to act, or an inability to act, are often the result.

This results because globalization dramatically changes the way states and markets interact, often fusing the public and private sectors in ways that can evoke a form of neocorporatism when it comes to the ways states carry out their

32. See Jost Delbrück, Globalization of Law, Politics, and Markets-Implications for Domestic Law-A European Perspective, 1 I Nd. J. Global Legal Stud. 9 (1993).

33. The state centric nature of U.S. public law makes this so.

34. For example, WTO decisionmaking processes are not transparent and participation beyond the parties to the case is limited. See Esty, supra note 27. 
publicly mandated goals. ${ }^{35}$ Rather than procedures substituting for political compromises over the substance of the underlying law involved, markets and market approaches are now used. Procedural laissez faire ${ }^{36}$ is replaced with what, to some, looks like substantive laissez faire itself, but to others is simply the pragmatic use of the market or, in effect, the reinvention of government. ${ }^{37}$ From a pragmatic point of view, markets take the place of procedures as a way of avoiding hard political choices. Markets and market approaches can cut costs in ways that politically accountable officials usually wish to avoid. Privatization of some governmental services may make it easier to cut budgets or eliminate unions. ${ }^{38}$ Moreover, a preference for markets by politicians can signal not only an ideological preference, but a kind of toughness as well. Markets can imply a degree of harshness that appears to be neutral and simply the logical consequence of processes over which we really have no individual control. For example, the idea of bringing market processes to bear not only in the management of prisons or welfare eligibility but, by implication, on prisoners and welfare recipients as well, may resonate with a political goal of ensuring that certain individuals in society do not benefit unduly at the public's expense. ${ }^{39}$ But such areas involve issues that inevitably are political in nature and would benefit from public awareness of, and input into, questions that focus not only on outcomes but the criteria used to assess. For example, who is or is not eligible for welfare, or what kinds of processes a private provider of prisons might or might not use for prisoners involved in a disciplinary proceeding.

The intersection of markets and the domestic political goals of some officials, however, should not obscure the fact that there are other more fundamental political economic factors that illustrate the ways that global forces, opportunities, and problems now influence the relationship of states and markets. Global competition affects states as well as the private sector. As governmental entities at all levels vie for funds and investment into their enterprises, low taxes and low-cost approaches to issues represent the currency with which

35. See generally Alan Cawson, Corporatism and Political Theory 22-46 (1986); Robert Perrucci, Japanese Auto Transplants in the Heartland (1994).

36. See generally Aman, supra note 3; Verkuil, supra note 3.

37. See generally Vice President Al Gore \& National Performance Review, Common Sense Government Works Better and Costs Less (1995).

38. See Aman, supra note 21, at 152-53.

39. See generally Developments in the Law: The Law of Prisons, supra note 13 (discussing cost, quality, and accountability in private prisons). 
they compete publicly. Market approaches are a part of the globally competitive landscape now. Along with the economics of governing, there are also the new realities of dealing with problems and actors that are global in scope. To be successful, states must partner not only with other states but also with the private sector. The interconnected nature of our economies, apart from the nonterritorial nature of problems such as global warming and air pollution, requires greater cooperation among states as well as a variety of new partnerships with nonstate actors. This is necessary not only to solve problems but to take advantage of opportunities as well. ${ }^{40}$ The result is a number of important changes in the ways current institutions, both domestic and international, state and nonstate, operate and interact with one another as well as a need for new understandings of the state's role in these activities. ${ }^{41}$ In this new context, public and private do not necessarily mean the same thing, and markets cannot automatically substitute more defined opportunities for democratic participation. Administrative law cannot remain the same either. It must, like the global actors and problems with which it deals, become multidimensional in its scope and reach, particularly if it is to deal effectively with the democracy deficits generated by globalization.

A new, multidimensional domestic administrative law potentially offers means for addressing the democracy deficits associated with globalization. The multidimensional aspect of a new administrative law derives from the fact that there is now both a public and a private dimension to lawmaking, and, in effect, both a vertical and a horizontal aspect to governance. Yet, because the horizontal aspects involve mostly private and nongovernmental entities, they are not, nor should they always be, susceptible to the vertical and hierarchical aspects of government and law that typify traditional public law. At the same time, not to take into account the decisionmaking and norm-creating powers of the private realm leaves too many values hidden from public view, unknowable and unaccountable. As we shall see, to deal with both the vertical and horizontal dimensions of

40. For example, municipal services can be provided more efficiently if the service area is conceptualized in optimal ways rather than on a territorial basis. See, e.g., Todd Wildermuth, Counties Consider Swapping Some Snow Removal Road Duties, Trin idad Plus \& The Raton Range, Mar. 24, 1998 "Certain roads in one county are more easily accessible from the neighboring county, making it convenient and time-effective for the neighboring county's crews to handle snow removal on those portions of road.").

41. See Alfred C. Aman, Jr., The Globalizing State: A Future-Oriented Perspective on the Publicl Private Distinction, Federalism, and Democracy, 31 VAnd. J. Transnat'l L. 769 (1998). 
global governance at the local level, and without automatically forcing them into a hierarchical state mode of decisionmaking, the new administrative law will have to be more focused on informational flows and democratic opportunities for participation and persuasion, and less on the procedural control of hierarchical decisionmaking power. Its purpose will be less focused on carrying out the goals of a particular regulatory regime, and more focused on how the information and the politics necessary to create such a regime are made possible in the first place. This will depend on the creation of the political spaces necessary to raise important policy issues in a timely manner. In this sense, the new administrative law can draw on some of the procedural innovations that have occurred in international law, another area of the law that must be deferential to various power centers without being oblivious to them. ${ }^{42}$

The democracy problem generated by globalization in this broad sense is increasingly a feature of modern life in the United States and abroad. A multidimensional, domestic administrative law offers an alternate approach to the democracy problem in at least some sectors of globalization. Commentators often refer to globalization as if it were a new supranational order, somehow "beyond" or "over" the sovereignty of individual states. ${ }^{43}$ I use the word "global" to refer to a transnational public and its interests and stakes in globalization, and not to make a claim to some universal interests. I see globalization as an open-ended set of dynamic and pluralistic processes that combine public and private lawmaking in novel, hybrid forms. My focus is on globalization at the domestic level-the domestic "face" of globalization, if you will-particularly where it involves the effects of delegations of state power to private domestic actors, such as private providers of prisons.

\section{State Centric and Denationalized Aspects of Globalization}

The prevailing analysis of globalization is state centric in nature. This may be because of what Robert O. Keohane and Joseph S. Nye refer to as the "Club Model of Multilateral Cooperation," exclusively involving states and their representatives for establishing rules and practices internationally. ${ }^{44}$ It may also be

42. See generally Abram Chayes \& Antonia Hander Chayes, The New Sovereignty 135-74 (1995).

43. See, e.g., Michael Hardt \& Antonio Negri, Empire (2000); Jeremy Rabkin, Why Sovereignty Matters 33-34 (1998).

44. See Claude Barfield, Free Trade, Sovereignty, Democracy 26 (2001) (discussing paper given by Keohane developing idea of the club model). 
that the perception of globalization as a "thickening" of the international field provokes a nationalist response that turns naturally to the state. ${ }^{45}$ To be sure, the legal responses to global problems usually are the responses of states, often in the form of multilateral treaties such as the Montreal Protocol on Ozone Depletion, or the creation of international organizations such as the World Trade Organization (WTO). Though the problems may be international in scope, the remedies are usually local, and states play a significant role in their implementation. But even in international organizations, or in the negotiations of multilateral treaties, the individual sovereignties of states are, in effect, pooled. The outputs of these treaty regimes and these international organizations are also, at least, partially denationalized. The very nature of the compromises necessary for individual states to engage in such multilateral forms of governance means that they are not likely always to be able to pursue their own national interests exclusively, or if they do, those interests usually are constructed with a more global sense of the problems involved and of what will constitute an effective solution.

State centric approaches emphasize national perspectives. A state centric approach to globalization also usually means bright-line distinctions between the public and the private sectors, and even more so, between domestic and international law. In so doing, however, state centric approaches often fail to distinguish between globalization and internationalization. They meet democracy concerns through the mechanism of state representation in international or multinational affairs. From a state centric perspective, multinational organizations (such as the WTO) are viewed as extensions of the state, as if they were macro-federal structures. In addition to the limitations already noted, this federal analogy overemphasizes the distinction between state and nonstate actors, essentially excluding the latter. ${ }^{46}$

Another aspect of globalization is denationalization. This term refers to processes that are essentially deterritorialized and potentially independent of states. This is especially true in the domains of economy, society, and culture. ${ }^{47}$ The denationalized aspects of globalization are highly dynamic processes that are not determined by fixed jurisdictions or boundaries between countries. Con-

45. See, e.g., Benjamin Barber, Jihad vs. MCWorld (1995) (discussing globalization and new nationalisms).

46. Jost Delbrück, Transnational Federalism: Problems and Prospects of Allocating Public Authority Beyond the State, Ind. J. Global Legal Stud., Winter 2004, at 31, 49-50 (2004).

47. See Saskia Sassen, Losing Control? Sovereignty in an Age of Globalization (1996). 
flating the global and the international neglects important differences between them, and ignores important resources for simultaneously strengthening the effectiveness of international organizations and the relevance of democracy among their member states. States thus remain highly relevant to our analysis; however, the essence of globalization as denationalization is the recognition that along with states, nonstate actors as well as international and supranational bodies are all significant players. These networks amount to governance more than government. ${ }^{48}$

States alone cannot solve global problems or fully take advantage of global market opportunities. As Phillipe C. Schmitter notes:

Governance is a method/mechanism for dealing with a broad range of problems/conflicts in which actors regularly arrive at mutually satisfactory and binding decisions by negotiating and deliberating with each other and cooperating in the implementation of these decisions.

Its core rests on horizontal forms of interaction between actors ... sufficiently independent of each other so that neither can impose a solution on the other and yet sufficiently interdependent so that both would lose if no solution were found. ${ }^{49}$

The essence of such a conception of cooperation and the successful exercise of power is that it depends less on hierarchy and more on the networks of actors involved. For example, the state centric nature of the WTO's structure and the legal power it wields are not inconsistent with a denationalized perspective on globalization. The breadth and impact of its decisions create, foster, and encourage stakeholders other than territorially bounded actors such as states. This is especially true when the decisions involve nontariff barriers to trade such as environmental laws. Indeed, a denationalized perspective makes broad-based participation and a transparent decisionmaking process a natural part of any

48. David Held et al., Global Transformations: Politics, Economics and Culture 50 (1999).

49. Phillipe C. Schmitter, What is There to Legitimize in the European Union . . and How Might This Be Accomplished? 7, available at http://www.iue.it/SPS/People/Faculty/ CurrentProfessors/PDFFiles/SchmitterPDFfiles/LegitimizeEU.pdf (last visited Jan. 2001). 
Privatization, Prisons, Democracy, and Human Rights 523

institution that is global in its impact. The crosscutting relations among the issues and the players require a process at least as broad as the impact of its outcomes. This is the first among my democracy criteria, to which we will return later.

A denationalized perspective on globalization highlights the need to emphasize networks and multiple decision sites and, if you will, a kind of global pluralism. Pluralism does not mean relativism in this context, but rather a decentralized system of deliberative decisionmaking that is interconnected by at least some common values and practices of legitimation. As a pluralist system, globalization is theoretically open. Problems of pollution, for example, are not bounded by territory, and even economic opportunities such as free trade involve a conception of markets that is not, in theory at least, limited by state jurisdictional lines.

The denationalized aspects of globalization are easily mistaken for statecentered processes and thereby easily neglected as a domain for domestic lawmaking and law reform. Because it is states doing the reacting to global issues or drawing our fire for failing to react, it is easy to miss the fact that most global processes are not at all state centered. The tendency to think in state centric terms-to say something is either private or public, domestic or internationalcannot capture the complexity of global processes, the diversity of the global networks and players involved, and the decentered nature of the state when it does react. There is in effect a gray zone that at present cannot be captured fully either by states or (by default) by markets. This gray zone is of interest to me because it is in the areas where a more pluralistic, denationalized approach can be instituted that administrative law comes into play. This is because state centric approaches to globalization take the issue at hand outside the domestic arena, or leave merely a rubber stamp. Most observers see globalization as essentially an international field comprised of states acting alone or together. However, I believe that viewing globalization instead as intersecting fields of transnational actors, both inside and outside the state sphere, yields both a richer understanding of the processes involved and a fuller account of democratic possibilities.

Globalization means that states must partner with other actors, both state and nonstate, if they are to solve problems that extend beyond their territorial reach. This brings us to another aspect of globalization, one that I believe is more telling in relation to the phenomena we tend to lump together under the rubric of globalization. Whether the issue is environmental pollution or the most efficient way of manufacturing and distributing automobiles, state jurisdictional 
lines are of ever-decreasing importance to the conceptualization and resolution of the question at hand. This does not mean that states and national interests are irrelevant. But it does mean that even when the externalities of globalization are identified, states account for only some of the actors involved. Considering globalization as denationalization facilitates understanding global lawmaking processes as inherently pluralistic, involving multiple actors representing various national and transnational networks.

With these different perceptions of globalization in mind, Part III now examines the delegations of public power to private entities in general, and then in depth, the delegation of public power to private prisons.

\section{Delegations to the Market}

\section{A. Privatization}

Privatization should be understood as a principal dynamic (i.e., both cause and effect) of globalization. It is not merely one means among many for making government more efficient or for expanding the private sector. Nor is it just a reflection of current political trends and a swing of the regulatory pendulum from liberal to conservative. Rather, the increasing reliance on "the new governance" is indicative of a changing relationship between the market and the state. It is characterized by a fusion of public and private values, rhetoric and approaches, a fusion that is itself integral to the fusion of global and local economies. Privatization is the result of these fusions. It, in effect, increases the exposure of the state to external economic and political pressures that tend to accelerate globalization, in large part, because private actors fully exposed to the global economy now carry out the delegated tasks. The global political economy places great pressures on all entities-public and private- to be cost effective if they wish to be competitive. This encourages such delegations on the part of the state and it raises concerns over whether the cost savings that result from such public delegations to private entities occur at the expense of democratic processes, legitimacy, and individual justice. Given the role that the public-private distinction plays in U.S. administrative law, privatization, in this global context, tends to reduce the democratic public sphere in favor of other arrangements that are likely to be less transparent and accountable to the public, and less exposed to competing value regimes. This is the essence of the democracy deficit. 
The democracy deficit is primarily the result of the application of a traditional conception of the public-private distinction that will likely diminish the public sector's responsibilities for transparency and accountability when private actors perform certain tasks. Justifications often provided for such an approach begin with the assumption that policymaking and administration can, in fact, be separated-an assumption that most commentators reject. Even in privatized contexts, private actors inevitably make policy when they carry out their delegated tasks and interpret the contracts under which they operate. A new kind of administrative law can and should be created to respond to the democracy deficit associated with privatization. It need not rely solely on traditional procedural approaches, arguably designed for governmental agencies carrying out regulatory functions. In fact, the role I envision for administrative law is not connected to regulation per se, but to democracy. It is important to emphasize that what is at stake are the values of public law-transparency, participation, fairness, and accountability, as well as the kind of democracy that can flow from all of these things. Various procedural approaches may be necessary to ensure the realization of these values. It is the democracy-creating values of the APA, though not necessarily the precise procedural devices it currently employs, that need to be extended to various hybrid, public-private arrangements, if we are to ensure the legitimacy of those partnerships.

The pragmatics of globalization make privatization one critical terrain in which a new administrative law might respond by assuring public forums for input and debate, and a flow of information that can help create meaningful politics around the decisions of private actors. The democracy problem is and should be one of the primary concerns of the new administrative law. There are, in effect, a variety of procedural responses possible to the procedural and structural questions presented by privatization. Perhaps the most common form of response is what we can call a traditional labeling approach: the actions taken are labeled either public or private. If public, a certain legal regime naturally follows with the application of the Due Process Clause; if private, another set of preordained rules may apply, including common-law approaches.

There are many problems with the labeling approach, particularly as applied to social services for the poor. Even if traditional due process protections extend to such contexts, the constitutional law that now exists may not be very effective and, in most instances, courts are increasingly reluctant to intervene. In any event, case-by-case approaches ignore the larger democratic needs that a space for politics might provide. Quite apart from the individual issues of a case, 
there are the larger policy issues that a purely economic discourse may ignore. However, if the private label is invoked, the resort to the common law, private remedies, and regimes may also be insufficient to deal with the public aspects of the problems involved. The emphasis is on suits based on retrospective facts, not on public participation in the creation of prospective rules. More important, and beyond what a private cause of action might provide, the problem with the labeling approaches is that they fail to recognize the reasons for the public-private questions now being presented. Those reasons involve nothing less than the transformative effect of the global economy on our legal system. There is now a need to devise responses that are sufficiently flexible to meet the demands of a world in which the relationship of markets to states is significantly different.

A new approach to administrative law is necessary-one that recognizes that global forces are not linear and that their market outcomes are not inevitable. Rather, administrative law can be a means of resisting some aspects of globalization while facilitating others. The public-private distinction need not be a source or primary cause of a domestic democracy deficit if we are willing to expand the province of administrative law, at least to the point of covering private actors carrying out public relationships. The following case study, dealing with private prisons, shows how this might be accomplished.

\section{B. Private Prisons}

"Despite its contemporary ubiquity, the prison is a relatively recent fixture in Western (indeed, every) society. Moreover, from the outset the prison was infused with private ownership and control, and with private functions, in many respects quite similar to the contemporary private prison." ${ }^{50}$ In the American colonial period, there existed almost no prison structure, and incarceration was almost never utilized for punishment. ${ }^{51}$ Where they existed, prisons were typically privately run. The workhouse, an antecedent to the penitentiary, was established in 1555 in England; these institutions (which worked prisoners and then charged them from their labor earnings) were primarily private.$^{52}$ In fact, "[t]he position of jailer itself was sold from one individual to another." The workhouse was a form of invest-

50. Ahmed A. White, Rule of Law and the Limits of Sovereignty: The Private Prison in Jurisprudential Perspective, 38 AM. CR1M. L. Rev. 111 , 122 (2001).

51. See Lawrence M. Friedman, Crime and Punishment in American History 48-49 (1993).

52. See Martin P. Sellers, The History and Politics of Private Prisons 48-49 (1993). 
ment. ${ }^{53}$ Until the U.S. Civil War, public prisons adopted various work requirements for prisoners, to the extent that many were self-sufficient and even declared profits. ${ }^{54}$ Even with the introduction of the public penitentiary, the private sector remained intertwined with the penal system; "[i]n the postbellum South, until at least the 1940s, the practice of substituting the plantation for the penitentiary continued in the guise of several different forced labor regimes." 55 For example, under the "criminal-surety" system, offenders convicted of minor crimes were allowed to exchange future labor to private citizens in return for payments of fines. ${ }^{56}$ California enacted a similar policy on an institutional scale: "the Prison Act of $1851 \ldots$ allowed prisoners to be turned over to contractors who would clothe, feed, and detain them in return for their labor." ${ }^{7}$ In 1885, " 13 states had contracts with private enterprises to lease out prison labor." ${ }^{58}$ It was not until the start of the twentieth century that it became the custom of correction agencies "to provide virtually all correctional services as governmental functions in institutions constructed and maintained at the government's expense." 59

The move back to private prisons began with the expansion of private services provided in prisons, which accelerated in the 1960s. These newly private services included "food preparation, vocational training, and inmate transportation." ${ }^{60}$ The first modern, privately operated prison was the Weaversville Intensive Treatment Unit, opened in 1976 in Pennsylvania. ${ }^{61}$ This facility was used for juveniles. Such inmates continue to constitute a disproportionate share of the private facility population. Currently, "more than 40,000 youth [are] now housed in privately operated juvenile facilities." ${ }^{2}$ Private prisons initially were slow to expand the number of inmates under their control. In 1987, there were only 3,100 inmates in private correctional facilities worldwide; in 1998 , that number had risen to $132,000 .{ }^{63}$

53. See id. at 49 (citation omitted).

54. See id. at 50-51.

55. White, supra note 50 , at 126.

56. Id. Often the convictions under these crimes were suspect to begin with, consisting of vagrancy and trespass violations.

57. Sellers, supra note 52 , at 50.

58. Bureau of Justice Assistance, Emerging Issues on Privatized Prisons 10 (2001) (citation omitted).

59. Id. at 11 .

60. Id.

61. Sellers, supra note 52, at 64.

62. Bureau of Justice Assistance, supra note 58, at 12.

63. Id. at iii. 
The predominant distribution of private prisons is in the South and Southwest, with almost no facilities existing in the East, Midwest, Upper Plains, or Pacific Northwest. ${ }^{64}$ This does not, however, mean that residents from these areas are the most likely to be housed in private prisons; $4,000 \mathrm{~W}$ isconsin prisoners are housed out-of-state, and Hawaii only has one prison within its borders because of high labor costs. ${ }^{65}$

Use of private prisons in the United States has coincided with the widely cited rapid growth of the number of inmates: "The population grew more than $400 \%$ from less than 320,000 in 1980 to nearly 1.4 million at the end of 2002 . The total population including those in jail was almost two million, with more than 1.8 million in state facilities." ${ }^{66}$ For comparative purposes, the U.S. houses approximately 700 prisoners per 100,000 people, while Europe averages approximately 110 per $100,000 .^{67}$

The United States having led the way, other nations have followed. To date they are Australia (1990), England and Wales (1992), Scotland (1997), New Zealand (1998), Canada (New Brunswick 1998), the Netherlands Antilles (1999), and South Africa (1999). Australia has the greatest proportion of its prison population in private prisons (about 20 percent); indeed, in one state, Victoria, almost 50 percent of prison accommodation is private. Of course, the numbers in Australia (ca. 4,000) are trivial by U.S. standards. The other most-developed jurisdiction, the United Kingdom, has about 10 percent of its inmates in private prisons. ${ }^{68}$

\section{Regulating Private Prisons: Toward a Model Statute}

Statutes involving the privatization of prisons vary widely from state to state in the protections they afford to the human rights of prisoners and the extent to which they involve the public at large, in a timely way, in such issues. Because

64. Id. at 5 .

65. White, supra note 50, at 139.

66. Robert P. Mosteller, New Dimensions in Sentencing Reform in the Twenty-First Century, 82 OR. L. Rev. 1, 13 (2003) (citations omitted). This author notes, however, that the rate of growth in America has drastically slowed.

67. Richard Harding, Private Prisons, 28 Crime \& Just. 265, 269 (2002).

68. Id. at 268 . 
"[m] ost government agencies have been satisfied with monitoring compliance with the terms of the contracts," ${ }^{19}$ it is imperative that statutes include human rights provisions that must be included in any private prison contract. Too often, however, there is little, if any, guidance in the applicable privatizing legislation. This is partly because decisions to privatize are often made hastily, usually in the face of budget pressures or court orders to relieve overcrowding at public facilities. Based on such realities, and given the presence of workable provisions scattered throughout state statutes in the United States, this paper suggests the establishment of a Model Privatization Code for prisons, incorporating many of these provisions found across the country. It also analyzes a number of prison privatization plans to illustrate why I believe they fall short of adequately protecting the general public's right to participate in such discussions, as well as the human rights of prisoners. I will first discuss the cost assumptions underlying the privatization of prisons. Next, I review prison services that can be privatized, but in ways that involve the general public and retain the government's accountability for human rights. Finally, I analyze the features of the criminal justice system that may involve too great of a sacrifice of human rights values to justify privatization.

\section{Privatization, Cost, Democracy, and Inequality}

There is a continuing debate about whether private prisons offer any real cost benefit at all. It is common, however, for some privatization statutes to require a minimum-percentage cost savings from private prison operators. ${ }^{70}$ While it can be argued that there would be little point in privatizing if some savings were not anticipated, as the cost-savings requirement gets larger, there is an increasing danger that private prisons would need to sacrifice prisoners' rights to meet the standard.

Contrary to popular wisdom, many states operate their own prison systems incredibly frugally. Alabama's public prisons, for example, spend $\$ 1.08$ per day to feed each prisoner. ${ }^{71}$ It is hard to see how private companies would necessarily be

69. Douglas C. McDonald et al., Private Prisons in the United States: An Assessment of Current Practice (1998), available at http:/www.abtassoc.com/reports/priv-report.pdf (last visited Apr. 7, 2005).

70. See, e.g., Ky. Rev. Stat. Ann. § 197.510(13) (Banks-Baldwin 1998) (requiring at least 10\% savings); Tenn. Code ANN. $\S 41-24-104$ (c)(2)(B) (2002 Supp.) (requiring at least 5\% savings); OHı Rev. Code Ann. 9.06(A)(4) (West 2002) (requiring at least 5\% savings); Fla. Stat. Ann. $\$ 957.07$ (West 2003 Supp.) (requiring at least $7 \%$ savings).

71. Carla Crowder, Alabama Feeds Prisoners on \$1.08 a Day, Birmingham News, Nov. 26, 2003, at A5. 
able to provide cost savings if the public authorities contract out for services such as food services without the generation of ever greater human rights concerns.

There are many other areas where public prisons are already run very frugally. In Alabama prisons, much of the work required to run the facility is performed by prisoners, which drastically reduces the costs of operation. "Prisoners chop wood, cut grass, grow vegetables, unload trucks, paint, sweep, mop and staff the kitchen. When new prisoners arrive on buses, old-timers are there to organize paperwork, take photos, cut hair and assist in delousing." ${ }^{\text {"I }}$ It is necessary to ask in privatized industries what costs have the legislators, in their statute, allowed to be lowered by the private entities, and what is the likely effect of the freedom given private companies in those provisions.

The Colorado privatization statute explicitly allows private providers to adjust worker wages and benefits: "[ $r$ he general assembly recognizes that such contracting may result in variances from legislatively mandated pay scales and other employment practices that apply to the state personnel system."73 In contrast, Washington, D.C. requires a private provider to offer displaced workers a right of first refusal for jobs with the private company, and further requires that private companies comply with the government pay scale for six months. ${ }^{74}$ The D.C. statute restricts a private provider's ability to meet cost targets by hiring more efficient workers or changing incentive structures; any required efficiency gains must, therefore, come from the reduction of other costs. The Colorado statute, like many others, requires that "privatization of government services not result in diminished quality in order to save money." 75

When privatizing prisons, however, an important question is from whose perspective is "quality" measured. Unless prison contracts entered into under the statute contain verifiable measures of quality, such statutory terms are, in all likelihood, unenforceable. With a few exceptions, states in the United States do a poor job of specifying what the state desires (besides low cost) to get for its agreement to employ a private prison provider. Michigan, in its statute allowing the privatization of juvenile-correction facilities, mandates that private providers of prisons require prisoners without high school degrees to receive a general

72. Id.

73. Colo. Rev. Stat. Ann. § 24-50-501 (West 2003).

74. See D.C. Code AnN. $§ 2-301.05 b(d)(2)-(4)$ (2003).

75. §24-50-501. 
equivalency diploma (GED). ${ }^{76}$ Colorado requires that private providers guarantee education services (and other services including dental, medical, psychological, diet, and work programs) of quality at least as high as public prisons. ${ }^{77}$ The problem with Colorado's provision is that it does not provide any specific, concrete standards by which a comparison of quality can be judged.

Part of the reason for concern about the potential for human rights abuses in private prisons is that the major rationales for the "relatively strong relationship between democratic forms of government and the protection of human rights"78 break down in the prison context. This means that most activities that would not require government retention of responsibility in other settings (such as the provision of food services in government buildings) might require such attention in the prison context. By democracy, I refer not only to electoral democracy, but the kinds of microdemocracies that administrative law can help create by providing for a steady flow of information and public participation in privatization discussions. The dialogue such transparency can inspire places an emphasis on bargaining and compromise to resolve disputes, one that helps to further the human rights of citizens. ${ }^{79}$ Additionally, information about private prisons can affect elections. It is argued that "democracies offer their citizens the ability to remove potentially abusive leaders before violations have become too severe." ${ }^{80}$ Furthermore, "the civil liberties usually associated with democracies ... enable citizens and opposition groups to publicize government abuses." ${ }^{81}$ These arguments lose their force in the prison context, where a defined minority of the population is stripped of both civil liberties and, often, the right to vote; prisoners are therefore excluded from the bargaining necessary to prevent oppression, and, especially in a privatized context, the general public usually is excluded from regular information about the treatment of inmates at prisons. Publicly-available information about cost and the contractual provisions is likely to replace a broader, political discourse in a privatized setting.

Publicity is hard to come by. The U.S. Supreme Court has held that neither the press nor the public has a constitutional right of access to prisons. In Houchins

76. See Mich. Сomp. Laws Ann. § 791.220g(11) (West 2001).

77. See Colo. Rev. Stat. Ann. § 17-1-202(f) (West 2003).

78. Wesley T. Miller, Economic Globalization and Rights: An Empirical Analysis, in Globalization and Human Rights 77, 83 (Alison Brysk ed., 2002).

79. See id.

80. Id.

81. Id. 
v. KQED ${ }^{82}$ a media plaintiff sought access to the wing of a county jail where a prisoner had committed suicide. The jail's condition allegedly caused the inmate's suicidal depression. At the time KQED commenced its suit, the prison did not conduct private tours, the inmates' mail was censored, and no interviews with inmates were permitted of any kind. KQED argued that the county's failure to provide adequate means for the public to become informed about the conditions of the jail violated the First Amendment.

The Court's plurality opinion, authored by Chief Justice Burger, noted that the Court in previous cases (also dealing with access to prisons) ${ }^{83}$ rejected a special right of access for the press beyond that afforded to the public in general. The Court further held that there was no discernible basis for a constitutionally imposed governmental duty to disclose newsworthy information. ${ }^{84}$ Chief Justice Burger concluded that the First Amendment did not mandate a right of access to information within the government's control. ${ }^{85}$ The Court's opinion would apply, most likely, with at least equal force to private prisons; Burger stated that "[t]here is an undoubted right to gather news 'from any source by means within the law, but that affords no basis for the claim that the First Amendment compels others-private persons or governments-to supply information." 86

\section{Minorities in Prison}

No thorough discussion of human rights issues in connection with U.S. prisons can be complete without some mention of the disparate representation of minorities in the U.S. legal system. A discussion of one state, Alabama, with a significant private prison population is instructive. The "clientele" of many private prisons is likely to be disproportionately minority; in Alabama, 73 percent of felony defendants are minorities. ${ }^{87}$ While Black males are much more likely to be subjected to prison time, and therefore have to live in a private prison, they are also correspondingly less able to influence either any privatization decision or any oversight protocols. It might be expected, for instance, that Blacks at

82. 438 U.S. 1 (1978).

83. See id. at 11 (citing Pell v. Procunier, 417 U.S. 817, 834 (1973) and Saxbe v. Wash. Post Co., 417 U.S. 843,850 (1973)).

84. See id. at $11-12$.

85. See id.

86. Id. at 11 (citations omitted).

87. Am. Bar Ass'n, Justice in Jeopardy: Report of the Commission on the 21 st Century JuDICIARY 43 (2003). 
Privatization, Prisons, Democracy, and Human Rights 533

high-level judicial positions would be able to influence somewhat the direction of the state's prison system. Yet despite Blacks' constituting 26 percent of Alabama's population, there is not a single African-American on any of Alabama's three appellate courts: the Alabama Supreme Court, the Alabama Court of Civil Appeals, and the Alabama Court of Criminal Appeals. ${ }^{88}$ Not only are AfricanAmericans underrepresented in positions of power within the judicial system, but currently over 30 percent of Black males in Alabama have lost the right to vote because of felony convictions, and "[t]he projection is that by the year 2005 the number could be as high as 40 percent." ${ }^{\prime 99}$ Alabama is not alone in its high disenfranchisement rate for African-American males; there are "more than 600,000 [disenfranchised felons] in Florida, not including those still in prison, on parole or on probation. More than one in four black men here may not vote. ${ }^{\prime 90}$

\section{Private Prisons-Transparency and Accountability}

Even if adequate democratic checks existed for prison privatization decisions, most states do not subject providers to enough oversight to ensure accountability for human rights protection. States take numerous approaches to the privatization issue, subjecting private service providers to differing degrees of public accountability. Most states have statutes regarding the privatization of prisons, some allowing and encouraging them, some banning their use altogether. ${ }^{91}$ A number of states also have general privatization statutes covering the privatization of any services. These general statutes reflect a variety of views toward privatization. For example, Colorado's privatization statute provides that "it is ... the policy of this state to encourage the use of private contractors for personal services to achieve increased efficiency in the delivery of government services." ${ }^{2}$ At the other end of the spectrum, the Massachusetts' privatization statute states that the legislature "hereby finds and declares that using private contractors to provide public services formerly provided by state employees does

88. See id.

89. Id.

90. Abby Goodhough, Disenfranchised Florida Felons Struggle to Regain Their Rights, N.Y. Times, Mar. 28, 2004, at Al.

91. See, e.g., N.Y. Correcr. Law $\$ 72(1)$ (McKinney 2003) (requiring the department to maintain custody of all inmates); ARK. CODE ANN. § 12-50-106(a) (Michie 2002) (authorizing contracts for construction, financing, and operating facilities).

92. Colo. Rev. Stat. Ann. § 24-50-501 (West 2003). 
not always promote the public interest." 93 The danger of statutes like Colorado's is that they state as fact the contentious issue of whether private providers are in fact more efficient; the statute assumes that private companies would more efficiently provide any service. This statute operates as a presumption that privatization is in the public interest, which may stifle debate on the actual merits of any individual privatization decision.

In order for a government to retain legitimate accountability for private prisons:

The state must retain and be able actually to exercise "step-in" rights-that is, to reclaim any privatized part of its prison systemand to do this it needs to have ongoing capacity and skill levels of its own. This can only be done if it remains a direct service provider in relation to some part, at least, of its prisoner population. ${ }^{94}$

For some services, such as janitorial services, the ability to "step-in" would not require the retention of a pool of state workers, even if such services were deemed to be a high human rights priority. For positions such as prison guards, in contrast, the state would have to retain a pool of public guards. Otherwise, if human rights problems developed at a private facility because of inadequate training, the state could not step-in with workers to take over security provision, and the state would likely have also lost the institutional ability even to train workers to perform the duties of a prison guard. In both 1982 and 1997 the Tennessee legislature considered, and rejected, proposals to privatize the state's entire prison system. ${ }^{95}$ The Correctional Corporation of America (CCA) promised the state that it would be able to save $\$ 100$ million per year with a completely privatized system. Not only would a state lose the ability to step-in if it accepted such a proposal, but if the private provider was really able to save such a large sum of money, it would be difficult to see how a state would be able to quickly take back a prison system. States have shown a propensity to spend or return in tax cuts any surplus money, and Tennessee, as a midsized state, would be hardpressed to come up with the money necessary to pay for the re-establishment of a public prison system in the event the private provider was unsatisfactory. The

93. Mass. Gen. Laws Ann. ch. 7, $\$ 52$ (West 2003).

94. Harding, supra note 67 , at 282.

95. See id. at $281-82$. 
ability of a state to step-in can be ensured, at least in part, through a "contestability" process where public providers are able to bid against private providers for contracts. Such a procedure, however, risks the removal of a governmental check on the dominance of economic concerns over human rights issues, insofar as the public providers are subjected to the same dominance of economic issues over noneconomic values in the provision of services.

"Even though there exist over a hundred privately operated secure confinement facilities [in the United States], there have been very few systematic attempts to compare their performance to that of public facilities. Most government agencies have been satisfied with monitoring compliance with the terms of the contracts." 96 The fact that most government oversight of private prisons concerns the monitoring of contract terms necessitates the inclusion of human rights provisions in privatization contracts. This is especially true given the increasing judicial indifference in the United States to prisoner suits, ${ }^{97}$ though the Supreme Court has recognized that private prisons and their employees are less immune from suit than their public sector counterparts. ${ }^{98}$

One way to increase the accountability of private prison operators to the state, and thereby ensure that the state retains ultimate responsibility for prisons, is to limit the length of the privatization contract. The Supreme Court recognized this form of accountability in Richardson v. McKnight, where a Tennessee statute limited a contract's term to three years. The majority stated that the firm's "performance is disciplined ... by pressure from potentially competing firms who can try to take its place. $"{ }^{99}$ Many states, however, do not specify a maximum contract length; some statutes explicitly allow for long-term contracts. Arkansas, for example, states that contracts with private prisons "may be entered into for a period of up to twenty (20) years." 100 On the other end of the spectrum, Ohio provides that a contract "shall be for an initial term of not more than two years, with an option to renew for additional periods of two years." ${ }^{101}$ Shorter contracts increase the po-

96. Douglas C. McDonald et al., Private Prisons in the United States: An Assessment of Current Practice 54 (1998), available at http://www.abtassoc.com/reports/priv-report.pdf (last visited Feb.17, 2004).

97. See Harding, supra note 67 , at 308.

98. See Richardson v. McKnight, 521 U.S. 399 (1997) (holding that private prison guards do not enjoy the qualified immunity in 42 U.S.C. $\S 1983$ cases that public prison guards do).

99. Id. at 410.

100. Ark. Code Anv. § 12-50-106(d) (Michie 2002).

101. Ohı Rev. Code Ann. $\$ 9.06($ A)(1) (West 2002). 
tential frequency of public input into the process, which would ideally be encouraged before contract renewal takes place.

A problem with the Court's praise of the short term provided by Tennessee law is that the Court assumed that there would be a number of firms available if the private provider should fall short in its performance. Whether there is any real competitiveness in the privatized-prison industry, however, is questionable because of its oligopolistic nature. As of December 31, 1998, over 76 percent of the private prison capacity was controlled by just two companies: Wackenhut Corrections Corporation (WCC) and CCA,${ }^{102}$ and CCA is a former subsidiary of WCC. ${ }^{103}$ When states privatize, they must realize that the benefits of any marketlike effects are concentrated in the period before a contract is entered. "The distinctive feature of contracting out is the element of ex ante competitioncompetition for the market as opposed to competition in it." 104 The imposition of long-term contracts between states and prison providers is likely to further concentrate the industry, by providing fewer opportunities for new companies to enter a market with a very limited number of potential customers.

In addition to the accountability-increasing feature of having a short potential contract period, Tennessee also provides that any private prison "must agree that the state may cancel the contract at any time after the first year of operation, without penalty to the state, upon giving ninety (90) days' written notice." 105 This provision encourages the state to oversee the running of any private prison more closely, because the delegation can easily be reconsidered. Private groups who are interested in the privatization of prisons also have an incentive to monitor the private provider more closely, because at any time after the first year they can lobby the state to rescind the contract if it becomes apparent that a different provider (either public or private) would be preferable. All privatization contracts that represent the possibility of significant infringements upon human rights should contain a provision allowing the state to cancel the contract if the state believes that human rights abuses may be occurring at a facility without fearing that the private provider might be able to hold the state liable for breach of contract. Clearly,

102. See James Austin \& Garry Coventru, Emerging Issues on Privatized Prisons 4 (2001).

103. Stephen Pounds, Prison Operator Makes Corrections to Expand, Palm Beach Post, Aug. 24, 2003, at $1 \mathrm{~F}$.

104. Simon Domberger \& Paul Jensen, Contracting Out by the Public Sector: Theory, Evidence, Prospects, Oxford Rev. Econ. Pol'y, Winter 1997, at 67, 68 (1997).

105. Tenn. Code Ann. §41-24-104(a)(4) (2003). 
prison guards have an important enough role to qualify-I would argue that medical providers do, as well. By contrast, janitorial and secretarial services would fit within the category of services that may be fully privatized.

Another important factor in retaining government responsibility for human rights abuses is the political accountability of the entity that actually makes the contract to privatize and what involvement other actors have in this process. To the extent that contracts become immutable, often even to later legislatures, and to the extent that, as mentioned above, states for the most part stick to contractual issues when policing private prisons, it is important that the participation of the public and the public's representatives be maximized as early in the process as possible. Tennessee's statute provides a complex contract-approval procedure involving several individuals and entities, but makes no provisions for the input of the general public. ${ }^{106}$ Any contract must be approved by the state building commission, the attorney general, and the commissioner of correction. ${ }^{107}$ Additionally, all proposals are reviewed by two congressional committees, which can make comments to those responsible for approving contracts before such approval takes place. ${ }^{108}$ All approved and proposed contracts are sent to the state and local government committees of both the senate and the house. ${ }^{109}$ While this procedure involves various members of the legislative and executive branch, it does not provide direct opportunities for the public in general to affect these officials' decisions. Nevertheless, at least the privatization procedure involves members of both the executive and legislative branches and includes legislators themselves, who are often very accessible to public input. In Idaho, the decision to enter into a contract with a private prison provider is left solely to the state board of correction; $;^{110}$ most of the public would not know whom to contact to affect privatization contracts or whom to hold accountable for the decisions of the board.

While several privatization statutes, such as Tennessee's, provide for some participation from the legislative branch in the contracting phase, few suggest any method for direct involvement from the public. One of the only states to call specifically for a public hearing does so in a statute covering all forms of government privatization. Montana requires an agency to form a privatization plan before any program can be privatized. Additionally the state provides that:

106. $\$ 41-24-104$.

107. $\$ 41-24-104(a)(1)$.

108. $\$ 41-24-104(\mathrm{a})(2)(\mathrm{A})$.

109. § 41-24-104(a)(2)(B).

110. See I daho Code $\$ 20-241$ A (Michie 1997). 
The privatization plan must be released to the public and any affected employee organizations and must be submitted to the legislative audit committee at least 90 days prior to the proposed implementation date. At least 60 days prior to the proposed implementation date, the legislative audit committee shall conduct a public hearing on the proposed privatization plan at which public comments and testimony must be received. At least 15 days prior to the proposed implementation date, the legislative audit committee shall release to the public a summary of the results of the hearing, including any recommendations of the committee relating to the proposed privatization plan. ${ }^{111}$

Florida "require[s] public sessions of the Correctional Privatization Commission to be held at which contract variations are [not only] discussed[, they are also] explained." ${ }^{112}$ Public hearings produce little benefit, however, if the public is not provided with adequate information with which to make informed suggestions. Kentucky law requires the production of information necessary for the public to make informed decisions about the quality and value of privatized services:

The private provider shall develop and implement a plan for the dissemination of information about the adult correctional facility to the public, government agencies, and the media. The plan shall be made available to all persons. All documents and records, except financial records, maintained by the private provider shall be deemed public records. ${ }^{113}$

Kentucky does not rely solely on voluntary disclosure by the provider to amass information on the functioning of privatized prisons. The legislature has also required that " $[t]$ he department shall annually conduct a performance evaluation of any adult correctional facility for which a private provider has contracted to operate. The department shall make a written report of its findings and submit this report along with any recommendations to the private provider and the Legislative Research Commission." 114 The prison privatization provi-

111. Mont. Stat. Ann. § 2-8-302 (2002).

112. Harding, supra note 67 , at 308 .

113. Ky. Rev. Stat. Ann. $\$ 197.510(7)$ (Michie 1998).

114. $\$ 197.515$. 
sions create a large quantity of data, and attempt to transmit most of the data to the public. They do not, however, provide any mechanism for the public to participate in the privatization decision, do not limit the length of any contract, and do not contain many concrete requirements for the actual running of the prisonsall of which would be necessary for meaningful accountability.

Most U.S. prison privatization statutes require certification by the American Correctional Association (ACA). As Richard Harding notes, however, "[i]mportant as [ACA] standards are in maintaining a level of accountability in U.S. corrections, they are primarily processual and formulaic. Practical, on-the-ground compliance or breach is seldom clear-cut, yet clarity and predictability are crucial for accountability." 115 Requiring certification, therefore, cannot absolve a state from responsibility for prison services touching on basic human rights such as prisoner safety. The United Kingdom and Australia do not require accreditation; the U.K system instead relies upon government prison inspections:

[t]he primary source of information, in contrast to ACA accreditation processes [where the ACA spends most of its time during announced visits reviewing a prison's written procedures], is direct observation, discussions with prisoners and staff, participation in some programs, follow-up interrogation of management, all this fortified with detailed scrutiny of documentation and records. ${ }^{116}$

By using government inspectors, the United Kingdom also maintains direct public oversight of prison conditions, a necessary element in preserving prisoner rights. Additionally, the United Kingdom—as well as Australia, Canada, and New Zealand-grant prisoners access to an ombudsman to whom prisoners can complain about violations of human rights by private prison providers. No such system is found in most U.S. systems. ${ }^{117}$

Statutes that clearly specify required elements of any prison privatization contract are preferable to those that establish few (or no) concrete requirements of the private entity in such contracts. In contrast to contract provisions, statutory language is readily accessible to the public; almost all of a state's statutory

115. See Harding, supra note 67 , at 303.

116. Id. at 318.

117. See id. at 319 . 
law can be located, free of charge, through the state's homepage. ${ }^{118}$ Additionally, even if the public cannot comment, legislative sessions are often open for the attendance of interested individuals. The Colorado General Assembly website allows the public to listen to the proceedings in the state house and senate, even including committee meetings. ${ }^{119}$ Furthermore, incorporating contract terms into a statute allows interested groups to focus their efforts on the design of every privatization contract in the state. Trying to influence each contract individually (even if the group would be notified before a contract was finalized) might often prove to be too taxing on an interested group's or individual's resources. Finally, legislatures are directly accountable to the public through elections, while entities such as state corrections boards are not.

In establishing a Model Privatization Code, it would be important to set up the basic requirements for ensuring that human rights are protected while leaving ample room for state experimentation with different procedures for enhancing the performance of private prisons. It is important to recognize that the current levels of privatization are unprecedented, and states may develop many insightful provisions to enhance the effectiveness of private prisons. Establishing a uniform code might actually aid such innovation, by enabling legislators to spend less time working out the basics of privatizing legislation, and, therefore, allowing consideration of state-specific (and other) concerns. Without some sort of guide for legislatures there is also the danger that the large private prison companies will be successful in establishing a uniform statute that represents primarily only their interests. Because, as mentioned above, many privatization decisions often seem to be made hastily by states, there is a danger that legislatures might pass such legislation without adequate consideration of human rights issues.

The private prison industry leaders are CCA, which has approximately 55 percent of the U.S. business, and WCC, with about 22 percent. Each also operates in non-U.S. markets through subsidiary companies that are usually " $\$ 2$ companies" formally incorporated but not capitalized in the local jurisdiction. In those

118. See, e.g., Colorado General Assembly Home Page, at http://www.leg.state.co.us (last visited Apr. 7, 2005); State of Arizona Home Page, at http://az.gov/webapp/portal (last visited Apr. 7, 2005).

119. See Colorado General Assembly Home Page, supra note 118. 
markets, WCC has 54 percent of the business, CCA 14 percent, and the British/Swedish Group 4 consortium 28 percent. ${ }^{120}$

This foreign ownership matters for several reasons. First of all, to the extent that international law holds private companies responsible for human rights abuses, such responsibility is greatly muted when underfunded subsidiaries are responsible for the complained-of practices. Additionally, "prison management is not simply a generic skill applicable anywhere on the globe but one that is to a significant degree culture specific." 121 In the context of human rights, this means that foreign prison management is potentially at a greater risk of violating human rights because of an inability to interpret cultural signals in an institutional context that is insulated from the host's society at-large.

\section{E. The Outer Limits of Privatization and Prisons}

\section{Disciplinary Hearings}

One of the inherent human rights problems created by the privatization of prisons is the blurred line between inmate discipline and the administering of additional prisoner punishment. Obviously, in order to run a prison effectively, the private provider must be able to assert some form of authority without clearance from a public supervisor. There is a point, however, where the discipline exacted by a private prison crosses over into punishment, and constitutional due process concerns require public oversight. In the United States many "disciplinary functions for breach of prison rules are carried out directly by the private operator." 122 In most U.S. jurisdictions inmates can receive time off their prison sentences for "good time" served; in other words, a prisoner's sentence is reduced for behaving well behind bars. While public prisons often have an incentive to credit prisoners for "good time" because of prison overcrowding, private prisons often have the opposite incentive because they are usually paid according to their daily occupancy. Guards at CCA facilities are given the option to buy company stock, and therefore "have a vested interest in maintaining high occupancy for a protracted period of time." 123

120. See Harding, supra note 67 , at 314-315.

121. Id. at 315.

122. Id. at 276.

123. Michael Welch, Punishment in America: Social Control and the Ironies of ImprisonMENT 291 (1999). 
These incentives have produced obvious results. "The New Mexico Corrections Department found that inmates at the [state's] CCA facility lost 'good time' eight times more frequently than prisoners in a state institution." 124 The revocation of "good time" amounts to a deprivation of liberty significant enough to require an action by the state. The United Kingdom retains state control over disciplinary matters: "[i]n all private prisons, disciplinary charges laid by custodial officers are adjudicated by ... public sector officials who work on-site." 125 Another prison procedure that should be subject to public official control is the imposition of administrative segregation. "In Tennessee, CCA guards say privately that they are encouraged to send balky inmates to administrative segregation; by placing prisoners in the 'hole,' the company earns an extra $\$ 1,000$ because 30 days are added to the sentence." 126

\section{Exporting Inmates}

In the United States, it is now common for inmates to be shipped to private prisons in other states, in an effort to find the lowest cost provider. "These arrangements are not only inimical to prisoners' best interests in terms of family visits, but they also stretch the chain of accountability beyond breaking point. The state of origin of the prisoners has no standing to regulate or supervise what happens within the private prison." 127 These transfers are often to distant states, increasing the "accountability deficit" created by these arrangements. For example, two of the largest prisoner-exporting states are the only two not within the contiguous forty-eight: Hawaii sends prisoners to Minnesota, and Alaska sends prisoners to Arizona. ${ }^{128}$ Another reason to develop a Model Privatization Code is that states often fail to consider all of the possible scenarios in which the switch to private prisons affects the status of the prisoners. For instance, when Oregon sex offenders housed in a Texas prison escaped in 1998, Texas officials were not even informed that they were housing these prisoners and "could not charge them with escape because in Texas it was not yet a crime to flee a private corporation." 129 CCA stated that "they had no legal obligation to notify city or

124. Id.

125. Harding, supra note 67 , at 276 (citation omitted).

126. WELCH, supra note 123, at 291 (citation omitted).

127. Harding, supra note 67 , at 280.

128. Id.

129. WELCH, supra note 123, at 289. 
Privatization, Prisons, Democracy, and Human Rights 543

county officials" of the transportation of sex offenders to their jurisdiction. ${ }^{130}$ This lack of information on the part of host states arguably violates a right to information on the part of citizens of the host state, who deserve to know potential risks to which they might be exposed because of private inmates. While such a lack of information might occur in prisons housing in-state offenders, the risks are greatly reduced.

Much of the pressure to privatize prisons is driven by cost. While every state has seen a dramatic increase in incarceration levels, Arizona's prison population has had increases of almost 1,000 percent in the last twenty-five years. ${ }^{131}$ The state is also facing a $\$ 1.3$ billion budget shortfall, leading to massive jail overcrowding. "The state's prisons are built to hold 26,000 inmates. They now hold more than $30,000 . " 132$ In the face of budget shortfalls, legislators are reluctant to spend money on prison construction, and this reluctance translates into a de facto ceding of increasing proportions of inmate housing to private facilities. One issue of growing national concern - but of greater effect in Arizona-is the housing of increasing numbers of foreign national prisoners. About 10 percent of Arizona's prisoners are Mexican nationals, and state officials have estimated that housing prisoners in Mexico could possibly save over $\$ 8,000$ per inmate each year. ${ }^{133}$ Arizona's senate in 2003 rejected a bill that "would have required the state to seek proposals from private prison operators to build and operate a prison within the neighboring Mexican state of Sonora." 134 This issue has been discussed in Arizona for several years, however, and it is likely that it or another state with high numbers of Mexican nationals (such as New Mexico) will experiment with a cross-border facility in the future.

Even more worrying is the emerging trend in the U.S. of "bed brokering," where private companies (such as Inmate Placement Services) find a prison bed in another state to house prisoners whom the home state cannot place. ${ }^{135}$ With

130. Id.

131. See Robert Nelson, Big House Inc.: Think More Private Prisons Would Be Good for Arizona? Think Again, Sucker, Phoenix New Times, Apr. 3, 2003, at A5.

132. Robert Nelson, Clink! Arizona's Prisons are Packed. Building More Would Cost Millions: Governor Janet Napolitano Wants to Lockup Even More People. But Others Say it May be Time to Let a Few Out, Phoenix New Times, Oct. 23, 2003, at A8.

133. See Howard LaFranchi, Arizona Plans to Export Mexican Inmates, Christian Sci. Monitor, June 17,1997 , at 8 .

134. Paul Davenport, Senate Panel Rejects Proposal to House Prisoners in Mexico, Assoc. Press Newswires, Mar. 7, 2003.

135. See Harding, supra note 67 , at 281. 
private prisons responsible for small numbers of inmates from numerous states, there is a danger that no individual state will have enough incentive to properly oversee human rights compliance, especially where the housing state does not send any of its own prisoners to the facility. Consequently, states should be required to house, and therefore retain responsibility for, their own prisoners.

In order to protect human rights, a state must also prohibit private providers, who either house inmates in the state or accept inmates from the state within facilities found in other states, from lobbying the state on criminal sentencing laws. It is true that private corporations can be more cost sensitive than public entities because of their accountability to shareholders. There is no evidence that private providers attempt to either influence sentencing decisions or statute drafting in order to increase the number of prisoners, thereby increasing their potential "clients." However, as private prisons begin to saturate markets and deepen their relationships with state legislators, prudent drafting should require that all prison privatization statutes make clear that contracting prisons are prohibited from lobbying the legislature on criminal-sentencing matters. Richard Harding has correctly stated the danger:

$[R]$ egulatory mechanisms in relation to private prisons are more susceptible to capture-that is, a situation where "regulators come to be more concerned to serve the interests of the industry with which they are in regular contact than the more remote and abstract public interest" - than in relation to other, more strictly commercial activities. ${ }^{136}$

It is, consequently, more important for the legislature to circumscribe the administering agency's discretion more than in other privatization contexts.

\section{Privatization of Interrogation During Wartime}

Privatization and the conduct of war, particularly the war in Iraq, has been a topic of great concern. ${ }^{137}$ Consider the current controversy surrounding Iraq and the Abu Ghraib prison. The Abu Ghraib scandal involves directly the problems that arise with the privatization of prisons, particularly with respect to human

136. Id. at 306 (citation omitted).

137. See generally P.W. Singer, Corporate Warriors: The Rise of the Privatized Military InDUSTRY (2004). 
rights. When a government contracts for the regulation and administration of prisons without adequate limitations concerning what actions are acceptable, and what are beyond the scope of reason (and perhaps even unlawful), and what treaties, laws, and regulations apply, the propensity for abuse can increase considerably.

When the Abu Ghraib scandal came into the media spotlight last year, a connection between prison regulation and private firm involvement also became apparent. As noted earlier in the paper, hiring private companies to handle general duties or tasks in the prison system is a fairly common practice; however, relegating the types of duties that were contracted out at Abu Ghraib is outside the scope of those general duties, and, as with disciplinary proceedings and the export of prisoners, raises a serious question of whether the interrogation of prisoners in wartime should be contracted out at all. Though the private companies hired by the U.S. Government were engaged in the interrogation of detainees and intelligence-gathering, ${ }^{138}$ the limited supervision given to these private contractors, and the abuse inflicted upon detainees by the employees of these firms, dramatically highlights the human rights abuses that can occur in such contexts by both public and private employees.

Article I of the United Nations Conventions Against Torture (CAT) and other cruel, inhumane, or degrading treatment or punishment defines torture as:

any act by which severe pain or suffering, whether physical or mental, is intentionally inflicted on a person for such purposes as obtaining from him or a third person information or a confession, punishing him for an act he or a third person has committed or is suspected of having committed, or intimidating or coercing him or a third person, or for any reason based on discrimination of any kind, when such pain or suffering is inflicted by or at the instigation of or with the consent or acquiescence of a public official or other person acting in an official capacity. It does not include pain or suffering arising only from, inherent in or incidental to lawful sanctions. ${ }^{139}$

138. See generally Julian Borger, US Military in Torture Scandal: Use of Private Contractors in Iraqi Jail Interrogations Highlighted by Inquiry into Abuse of Prisoners, THE Guardian (London), Apr. 20, 2004, Guardian Home Pages at 1.

139. United Nations Convention Against Torture and Other Cruel Inhuman or Degrading Treatment or Punishment, art. 1, available at http://www.hrweb.org/legal/cat.html (last visited Feb. 17, 2005). 
The investigation into the Abu Ghraib scandal has, thus far, yielded a substantial number of possible human rights violations-extending from the use of humiliation tactics (forcing detainees to stand naked, simulate sexual acts with one another, be dragged around in chains like animals, etc.) to brutality, all of which may constitute torture. ${ }^{140}$

When granting government contracts to private firms for the regulation and management of prisons, certain mechanisms must be in place to ensure that human rights are upheld and abuses are kept to a minimum. Without adequate measures to guarantee that private companies are accountable to the government, the ambiguity as to who gives the orders can lead to situations like Abu Ghraib. There is a question as to whom the private contractors working at Abu Ghraib answered, if there even were persons to answer to. ${ }^{141}$ Owing to the somewhat uncertain legal status of the private contractors, coupled with the confusion as to what laws apply to them, holding private individuals responsible for human rights violations in circumstances like that of Abu Ghraib could be problematic. ${ }^{142}$

Two recently released reports by independent commissions (hereinafter Schlesinger and Fay) note various concerns and problems with the structuring of direction and command with respect to Abu Ghraib. ${ }^{143}$ These problems are only made more severe by the use of private firms to conduct interrogations of the Iraqi prisoners. Schlesinger elaborated upon Fay, noting that interrogators were not properly trained. Owing to the absence of training, interrogators used their own methods and practices, implementing original techniques that contributed to abusive behavior. ${ }^{144}$ The findings of the two independent commissions support the

140. See generally Borger, supra note 138.

141. See generally Joel Brinkley \& James Glanz, Contractors in Sensitive Roles, Unchecked, N.Y. Times, May 7, 2004, at A 15; David Leigh, Allegations of Abuse Have Raised Wider Questions About the Role-And Accountability-Of Civilian Contractors: Who Commands the Private Soldier?, THE Guardian (London), May 17, 2004, Guardian Home Pages at 4; James Rosen, Contractors Operate in a Legal Grey Area; The Roles of an Interrogator and an Interpreter in the Abuse Scandal are Murky: Even Less Clear Is Whom They Answer To, StaR TRIbUne (Minneapolis, MN), May 23, 2004, at 11 A. 142. See Joshua Chaffin, Contract Interrogators Hired to Avoid Supervision, Fin. Timrs, May 21, 2004, at Middle East 8.

143. See generally James R. Scheslinger, Final Report of Independent Panel to Review Department of Defense Detention Operations [hereinafter Schlesinger Report], available at http://news.findlaw.com/hdocs/docs/dod/abughraibrpt.pdf (last visited Apr. 7, 2005); MG GEORGE R. Fay, AR 15-6 Investigation of the Abu Ghraib Detention Facility and 205th Military InTElligenCE BRIGADE [hereinafter FAy RePORT], available at http://news.findlaw.com/hdocs/docs/ $\operatorname{dod} /$ fay82504rpt.pdf (last visited Apr. 7, 2004).

144. See Schlesinger Report, supra note 143, at 38. 
theory that with stronger administrative safeguards and better delegation of authority, perhaps these types of violations could have been avoided.

While Schlesinger incorporated the offenses committed by the military and civilian contractors into one general discussion, Fay specifically addressed the issues and concerns raised by the contracting of private firms, especially CACI International, Inc., the private firm obtained for interrogation and other intelligence gathering purposes. ${ }^{145}$ The report indicated that CACI employees, hired for "numerous intelligence-related services" including "interrogator support," "screening cell support," "open source intelligence," and "special security office," among others, were able to participate in the abusive tactics, in large part because of the lack of administrative restraints. ${ }^{146}$ Both commissions recognized the need, at times, to employ private companies, specifically in "urgent" or "emergency" situations, but also emphasized that:

The general policy of not contracting for intelligence functions and services was designed in part to avoid many of the problems that eventually developed at Abu Ghraib, i.e., the lack of oversight to insure that intelligence operations continued to fall within the law and the authorized chain of command, as well as the government's ability to oversee contract operations. ${ }^{147}$

Fay further noted that if private contractors were necessary for interrogation purposes, then there must be a carefully developed structure including technical requirements, personnel requirements, and training. ${ }^{148}$

These findings by Fay and Schlesinger, at a minimum, support the theory that when granting government contracts in areas as sensitive as the maintenance of prisons during wartime, where contractors have direct interaction with detainees, administrative mechanisms ensuring accountability are essential to preventing human rights violations and abuses. Both reports include specific recommendations regarding what policies need to be implemented, should the government have to resort to delegating responsibilities like interrogation and intelligence gathering. Fay expressed serious concerns regarding the extent to

145. See FAY Report, supra note 143, at 48.

146. Id. at $48-49$.

147. See id.

148. See id. 
which private firms were aware that they, too, must follow the requirements of the Geneva Conventions, and develop their techniques accordingly, so as to uphold the law. ${ }^{149}$

\section{Conclusion}

Privatization has been one of the primary forms of marketization in the United States. Some might say that there is not a great tradeoff for democracy if snow removal is shifted from a city garage to a private contractor or even if a publicly operated prison is now managed by a for-profit, private corporation. But the fact that such trends in management are driven by global processes assures us that a larger transformation is underway. The connection between the relatively minor example of snow removal and the more significant change in approach to the management of prisons is in their common connection to globalization and the structural aspects of their insulation from the public.

Democracy involves and requires more than just market forces and outcomes. It involves and requires more than representation and a chance to hold public officials accountable through the ballot box. ${ }^{150}$ Legitimacy comes in many forms and through many forums. Administrative law can facilitate the creation of multiple forums for policy discussions to occur and, if necessary, politics to develop if contractual obligations are not met or need to be revised. Focusing on the democracy deficit brought about by globalization does not mean that only traditional legitimacy arguments, so common in administrative law, are relevant. $^{151}$ In fact, there is a major difference between legitimacy concerns expressed in traditional public law terms and today's concerns with privatization. We have moved from questions concerning the proper role of judges, as opposed to legislators, when it comes to policymaking, to issues concerning whether there will be any public input at all when we are dealing with private contractors. It is not just a connection with an elected official that matters. What matters more are opportunities for interested individuals to have input in policymaking processes, as well as the specific cases that may affect them.

149. Id. at 50 .

150. See Edward Rubin, Getting Past Democracy, 149 U. PA. L. Rev. 711 (2001).

151. See Alfred C. Aman, Jr., Proposals for Reforming the Administrative Procedure Act: Globalization, Democracy and the Furtherance of a Global Public Interest, 6 IND. J. GLobal Legal Stud. 397 (1999). 
Beyond traditional notions of electoral accountability, democracy requires the means by which issues can be drawn, information shared, and meaningful politics created. Democracy involves multiple forums for values and views to be expressed publicly on issues beyond those likely to be relevant to just an economic conception of the problems at hand. Legitimacy requires more than a process simply to check up on those in positions of responsibility to see if they are doing their job. It also involves creating the kind of in formation necessary to understand the issues for a real debate to ensue and for new ideas to be suggested. Administrative law can and should play an important role in making forums available to consider and assess new approaches to issues, not only those considered by public agencies but by public-private hybrids as well. The public-private distinction should not unduly shield decisionmaking processes from opportunities for participation and the articulation of values and points of view that enrich our politics and, indeed, make meaningful political discussion possible.

Closely related to these democracy concerns are questions of citizenship. Quite apart from the decisionmakers involved, how do we conceptualize those affected by these decisions? In addition to being citizens, individuals are increasingly treated as consumers, customers, and clients. Each of these labels-citizen, customer-consumer, and client-carry different expectations with regard to individual and collective responsibility for the provision of services. At what point does the convergence of market processes, private decisionmakers, and individuals as consumers, customers, or clients actually undercut our ability as citizens to engage in the broader kinds of participation necessary for a vibrant political process $?^{152}$ It is important that the legal discourses triggered by the publicprivate distinction do not undercut or mask the role that citizens need to play.

A third related set of issues for the new administrative law involves conflict of interest concerns. The state centric aspects of traditional administrative law have focused primarily only on public administrators. Regarding conflict questions, the law asks such questions as whether there is a personal economic interest

152. See Hindy Lauer Schacter, Reinventing Government or Reinventing Ourselves 7-9 (1997). 
tied to the decision involved, ${ }^{153}$ whether there is inappropriate ex parte ${ }^{154}$ contact, or whether there is undue bias on the part of the decisionmaker. ${ }^{155}$ Economic gain is a particularly relevant criterion when applied to some forms of privatization, such as those where the decisionmakers involved are chosen in part because of the incentives provided by their duty to try to make a profit. Clearly, to obviate this problem the parameters of the delegated task must be set forth with clarity. Delegation-like doctrine requirements can and should surface in this context since it can only be assumed that a private prison provider will want to carry out its duties in as profitable a manner as possible. To assure that this does not include trampling prisoners' rights, legislative and contractual detail is necessary. Such an approach can thus eliminate a financial conflict by making clear the challenges the contractor must meet before any profit is possible.

The province of administrative law is broad. It can and should involve the application of public law values to private actors and the creation of informal approaches to ensure a multiplicity of voices are heard and that noneconomic, as well as economic, issues are considered. In this way, human rights abuses may not only come to light, but more importantly, may never occur at all.

153. See, e.g., Tummey v. Ohio, 273 U. S. 510,532 (1927):

[T] argument that men of the highest honor and the greatest self-sacrifice could carry it on without danger of injustice. Every procedure which would offer a possible temptation to the average man as a judge to forget the burden of proof required to convict the defendant, or which might lead him not to hold the balance nice, clear and true between the State and the accused, denies the latter due process of law.

154. 5 U.S.C.S. $\S 557(\mathrm{~d})(1)(\mathrm{B})$ :

$[\mathrm{N}] \mathrm{o}$ member of the body comprising the agency, administrative law judge, or other employee who is or may reasonably be expected to be involved in the decisional process of the proceeding, shall make or knowingly cause to be made to any interested person outside the agency an ex parte communication relevant to the merits of the proceeding.

155. See, e.g., United States Steel Workers of America v. Marshall, 647 F.2d 1189 (D.C. Cir. 1980). 